БРАНІЦКИЙ Юрій Юрійович - директор Уладово-Люлинецької дослідно-селекційної станції ІБКІЦБ НААНУ (22422, Вінницька обл., Калинівський р-н, с. Уладівське, вул. Семполовського, 15, E-mail: selekstanciya @ gmail.com)

БУЗИННИЙ Микола Володимирович - кандидат сільськогосподарських наук, директор Білоцерківської дослідної селекційної станції ІБКЦБ НААН України (09175, Київська обл., Білоцерківський район, с. Мала Вільшанка, вул.. Центральна, 1

E-mail: bcdss1893@gmail.com)

PRONKO Lyudmila - PhD, associate professo, Department of administrative management and alternative energy sources, Vinnitsa National Agrarian University (21008, Vinnitsa, 3, Soniachna str., e-mail: pronkoL@ukr.net).

BRANITSKYY Yuriy - Director of the Vladivo-Lyulinets Research and Breeding Station of the IBKICB NAANU (22422, Vinnytsia region, Kalynivskyi district, Vladovske village, Sempolovsky St., 15, E-mail: selekstanciya@gmail.com)

BUZYNNYI Mykola - PhD, associate professor, Director of the Belotserkovsky Experimental Breeding Station of the IBCCC of the National Academy of Sciences of Ukraine (09175, Kyiv region, Bilotserkivskyi district, Mala Vilshanka village, 1 Centralna str., 1, Email: bcdss1893@gmail.com)

ПРОНЬКО Людмила Николаевна - кандидат экономических наук, доцент кафедры административного менеджмента и альтернативных источников энергии, Винницкий национальный аграрный университет (21008, г. Винница, ул. Солнечная, 3, e-mail: pronkoL@ukr.net).

БРАНИЦКИЙ Юрий Юрьевич - директор Уладово-Люлинецькоq опытно-селекционной станции ИБКИЦБ УААН (22422, Винницкая обл., Калиновский р-н, с. Уладовское, ул. Семполовського, 15, E-mail: selekstanciya@gmail.com)

БУЗЫННЫЙ Николай Владимирович - кандидат сельскохозяйственных наук, директор Белоцерковского исследовательской селекционной станции ИБКЦБ НААН Украины (09175, Киевская обл., Белоцерковский район, с. Малая Ольшанка, ул . Центральная, 1, E-mail: bcdss1893@gmail.com)

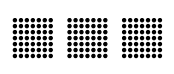

УАК: $330.341: 33.112 .1: 330.554 .2$

DOI: $10.37128 / 2411-4413-2019-6-3$

\section{ВПЛИВ СОЦІАЛЬНО-ЕКОНОМІЧНИХ ЧИННИКІВ НА ФОРМУВАННЯ СПОЖИВЧОГО ПОПИТУ ${ }^{\odot}$}

БРОЯКА А.А., кандидат економічних наук, доцент, доцент кафедри економіки, Вінницький національний аграрний університет (м. Вінниця)

Стаття присвячена дослідженню сучасних підходів до формування спожсичого попиту. Здійснено класифікацію видів різноманітних чинників, ще впливають на поведінку споживача $i$ прийняття ним рішення про закупівлю товару чи послуги, на основі чого виділено види споживання. Враховуючи вступ в епоху консюмеризму, приділено увагу дії мережевих ефектів, зокрема ефекту наслідування та ефекту сноба. Розглянуто їхній вплив на споживача з погляду економічної теорії та проілюстровано результат їхньої дії на споживчий попит за допомогою графічних моделей. Здійснено аналіз особливостей споживання в Украйні в сучасних умовах, які зумовлені диферениіацією життєвого рівня населення. Досліджено динаміку зміни обсягів та структури доходів і витрат українців. Виявлено падіння купівельної спроможності та збільшення ознак 


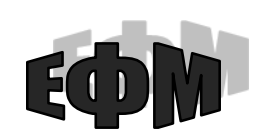

http://efm.vsau.org/

депривації вітчизняних споживачів, щзо підтверджується, серед інших чинників, $і$ зменшенням обсягів споживання продуктів харчування протягом останніх п'яти років усіх видів продукції. Надано рекомендації щзодо заходів, спрямованих на стимулювання росту споживчого попиту.

Ключові слова: споживчий попит, поведінка споживача, ефект наслідування, ефект сноба, доход, витрати, купівельна спроможність.

Табл. 2. Рис. 4. Літ. 14.

\title{
INFLUENCE OF SOCIO-ECONOMIC FACTORS ON CONSUMER DEMAND FORMATION
}

\author{
BROYAKA Antonina, \\ Candidate of Economic Sciences, \\ Associate Professor of Economics Department, \\ Vinnytsia National Agrarian University
}

(Vinnytsia)

The article is devoted to the study of modern approaches to the formation of consumer demand. The classification of the types of various factors influencing the consumer's behavior and deciding on the purchase of a product or service has been made, on the basis of which the types of consumption are distinguished. Given the advent of the era of consumerism, the attention is paid to the network effects, in particular the Bandwagon effect and the Snob effect. Their influence on the consumer from the point of view of economic theory is considered and the result of their influence on the consumer demand by means of the graphical models is illustrated. The analysis of consumption peculiarities in Ukraine in modern conditions, which are conditioned by the differentiation of the standard of living of the population, has been carried out. The dynamics of changes in the volume and structure of income and expenditure by Ukrainians has been investigated. The decline in purchasing power and increase in signs of deprivation of domestic consumers is revealed, which is confirmed, among other factors, with decrease in food consumption over the last five years by all types of products. Recommendations on measures aimed at stimulating consumer demand growth are given.

Keywords: consumer demand, consumer behavior, imitation effect, snob effect, income, cost, purchasing power.

Tab. 2. Fig. 4. Lit. 14.

\section{ВЛИЯНИЕ СОЦИАЛЬНО-ЭКОНОМИЧЕСКИХ ФАКТОРОВ НА ФОРМИРОВАНИЕ ПОТРЕБИТЕЛЬСКОГО СПРОСА}

\author{
БРОЯКА Антонина Анатольевна, \\ кандидат экономических наук, доцент, \\ доцент кафедры экономики, \\ Винницкий национальный аграрный университет \\ (2. Винница)
}

Статья посвящена исследованию современных подходов к формированию потребительского спроса. Осуществлена классификачия видов различных факторов, влияющих на поведение потребителя и принятия им решения о покупке товара или услуги, на основе чего выделены виды потребления. Учитывая вступление в эпоху консюмеризма, уделено внимание действию сетевых эффектов, в частности эффекта подражания и эффекта сноба. Рассмотрено их влияние на потребителя с точки зрения экономической теории и проиллюстрировано результат их воздействия на потребительский спрос с помощью графических моделей. Осуществлен анализ особенностей потребления в Украине в современных условиях, которые обусловленны дифференциацией жизненного уровня населения. Исследована динамика изменения объемов и структуры доходов и расходов украинцами. Выявлено падение покупательной способности и увеличения признаков депривации отечественных потребителей, что подтверждается, среди прочих факторов, и уменьшением объемов потребления продуктов питания в течение последних пяти лет по всем видам продукции. Даны рекомендации по мерам, направленным на стимулирование роста потребительского спроса.

Ключевые слова: потребительский спрос, поведение потребителя, эффект подражания, эффект сноба, доход, затраты, покупательная способность.

Табл. 2. Рис. 4. Лит. 14. 
Постановка проблеми. Нестабільність економічної ситуації в Україні, падіння купівельної спроможності населення та загострення конкурентної боротьби виробників за ринки збуту істотно вплинули на обсяги й структуру споживання товарів та послуг в країні. Зростання цін на базові товари, підвищення тарифів на комунальні послуги змушують українців заощаджувати, відмовляючись від непріоритетних товарів. Як наслідок, виробники та продавці повинні систематично переглядати та оптимізувати свій асортимент, змінювати свою торговельну політику аби уникнути неочікуваних матеріально-фінансових втрат. Тому вивчення ринкової поведінки споживачів $є$ завжди актуальним питанням, що дозволяє вчасно корегувати стратегію розвитку підприємств аби максимально відповідати очікуванням своїх потенційних покупців.

Аналіз останніх досліджень та публікацій. Питання формування споживчого попиту розглядалося різними економічними школами. Перші основи цього поняття було закладено ще А. Смітом та Д. Рікардо, а подальший розвиток під різними кутами отримало у працях всесвітньо відомих вчених

А. Маршалла, Л. Вальраса, Дж. Кейнса та ін. Вагомий вклад у дослідження вибору та поведінки споживача здійснили В. Парето, П. Самуельсон, Дж. Хікс, Т. Веблен Й. Шумпетер, Є. Слуцький та ін. Серед сучасних українських вчених, що займаються проблемою поведінки споживача варто виділити К.В. Бажеріну [1], Т.В. Бондарчук [2], Т.О. Гуржий [4], О.В. Свтушевську [6], Т. Жовковську [8], В.В. Каправого [10], І.Л. Решетнікову [13], М.П. Сагайдак [13], Ю. Сюсель [14], Л.О. Шкварчук.

Аналізуючи існуючі наукові праці, можна зробити висновок, що споживчий вибір, хоч i підпадає під дію певних закономірностей, видозмінюється з плином часу та трансформацією соціально-економічних умов існування споживача. Стимулювання економічного розвитку країни тісно пов'язане із особливостями поведінки вітчизняного споживача, обсягами та структурою споживчого попиту. Тому дослідження різноманітних чинників, що обумовлюють споживчий вибір, набувають особливого значення в період кризи споживання, яку переживає національна економіка на сучасному етапі.

Формулювання цілей статті. Метою статті $є$ аналіз широкого спектру соціальноекономічних чинників поведінки споживача та дослідження їхнього впливу на формування споживчого попиту.

Виклад основного матеріалу дослідження. Згідно класичного економічного погляду, споживання - це «кінцева фаза суспільного відтворення, в якій суспільний продукт використовується для задоволення потреб людей» [14, с. 28]. Воно може бути виробничим і невиробничим. У своєму дослідженні ми концентруємо увагу на особистому (невиробничому) споживанні та споживацькій поведінці індивідів, спрямованої на забезпечення власної життєдіяльності та розвитку. Споживання є суб'єктивним явищем, оскільки його структура та обсяги залежать від уподобань та фінансових можливостей конкретного споживача. Водночас, на поведінку споживачів впливають й інші ендогенні та екзогенні чинники, які можна згрупувати за спільними ознаками, а саме: особистісні, психологічні, економічні, соціокультурні, політичні (рис. 1). Причому перелічені чинники можуть діяти на індивіда одночасно і навіть у протилежних напрямках. У залежності від сили їх впливу на особистість споживач приймає рішення щодо закупівлі того чи іншого виду та обсягу продукції. Узагальнюючи типову споживчу реакцію на вплив різних чинників, можна виділити декілька видів споживання, зокрема: осмислене, професійне, матеріалістичне, демонстраційне, аскетичне, лотерейне, ностальгійне, патологічне, патріотичне.

В економічних дослідженнях прийнято вважати, що поведінка споживача є раціональною, тобто, в межах окресленої нами класифікації, вона є осмисленою (споживач знає чого він бажає), матеріалістичною (спрямованою на максимальне задоволення своїх безмежних потреб) в умовах обмеженості бюджету. Значна частина закупівель товарів та послуг здійснюється з урахуванням роду занять індивідів. Переважно професійне споживання здійснюється підприємствами (закупівля оргтехніки, канцтоварів, меблів тощо), але в цьому випадку таке споживання буде віднесене до виробничого. Професійне ж індивідуальне споживання більше стосується саморозвитку особистості, наприклад: відвідування тренінгів, виставок, закупівля відповідної літератури, засобів для виготовлення власноручної продукції тощо.

В умовах розвиту «суспільства споживання» та консюмеризму все більшого значення набуває демонстраційне споживання. Вперше цей термін був застосований Торстейном Вебленом у науковій праці «Теорія дозвільного класу» [10], на думку якого демонстраційне споживання спрямоване на закупівлю більш дорогої, непершочергової продукції, що підтверджує вищий рівень 
http://efm.vsau.org/

доходу та статус споживача. У сьогоденні демонстраційне споживання підсилюється дією мережевих ефектів, зокрема ефектом наслідування та ефектом сноба. Обидва зазначені ефекти передбачають вплив інших людей на індивідуальний вибір споживачем тієї чи іншої продукції, причому перший діє позитивно, а другий - негативно.

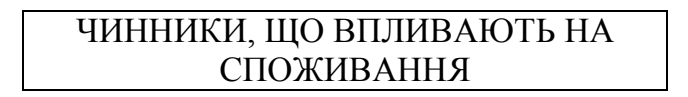

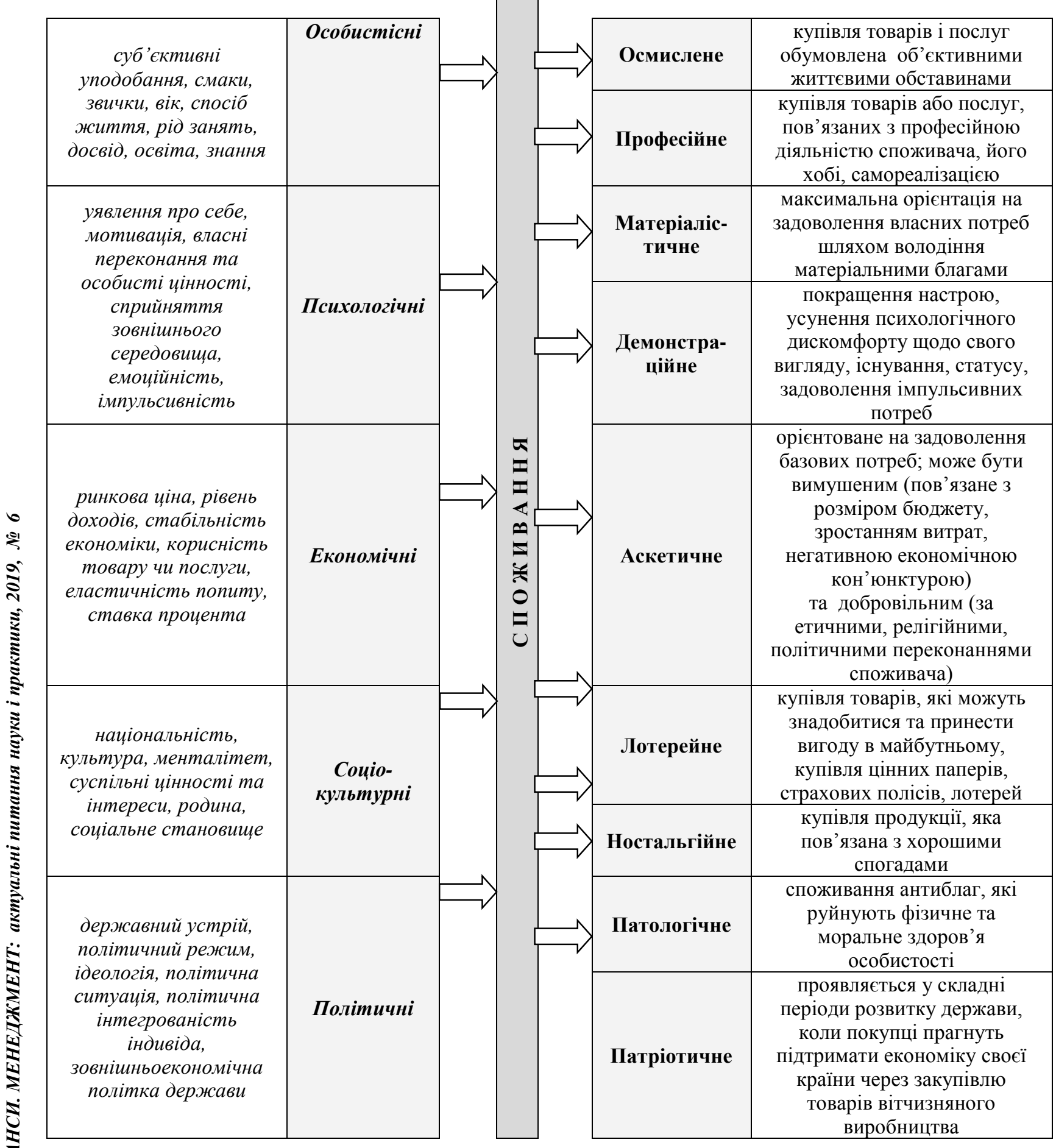

\section{Рис. 1. Види споживання та чинники, що на нього впливають}

Джерело: сформовано автором на основі [2, 6, 7, 8, 13]

Ефект наслідування ще називають ефектом приєднання до більшості. Він має вагоме значення для виробників та продавців, оскільки уможливлює збільшення обсягів продажу та виручки від реалізації внаслідок масового споживання модного та корисного на думку суспільства продукту. 3 мікроекономічної точки зору цей ефект означає, що індивідуальний попит конкретного 


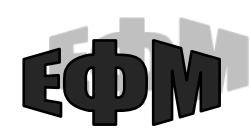

http://efm.vsau.org/

споживача на певний товар тим вищий, чим більше інших споживачів купують цей самий товар. Таке наслідування порушує класичне розуміння теорії попиту, яке передбачає, що споживачі приймають рішення про покупку виключно на основі ціни і особистого уподобання, та впливає на розташування й нахил кривої попиту (рис. 2.а). Чим більше осіб купують певний товар, тим далі від початку координат буде розташована крива індивідуального попиту споживача. При знижені ціни 3 рівня $P_{1}$ до $P_{2}$ без впливу ефекту наслідування діятиме класичний закон попиту і обсяг споживання збільшиться з $Q_{I}$ до $Q_{2}$, а завдяки ж приєднанню до більшості споживач переміститься на нову криву попиту $d_{2}$ і його обсяг попиту зросте до рівня $Q_{2}$. Проте, ефект наслідування та ціновий ефект обидва базуються на законі попиту і відображають прагнення споживачів купувати більше по нижчій ціні, таким чином вплив першого підсилює дію другого. У результаті приєднання споживачів до більшості утворюється крива ринкового попиту $D$, яка $є$ більш еластичною, ніж окремі індивідуальні криві попиту, а реакція споживача на зменшення ціни буде відповідати сумі зміни обсягу попиту від чистого цінового ефекту та ефекту наслідування.

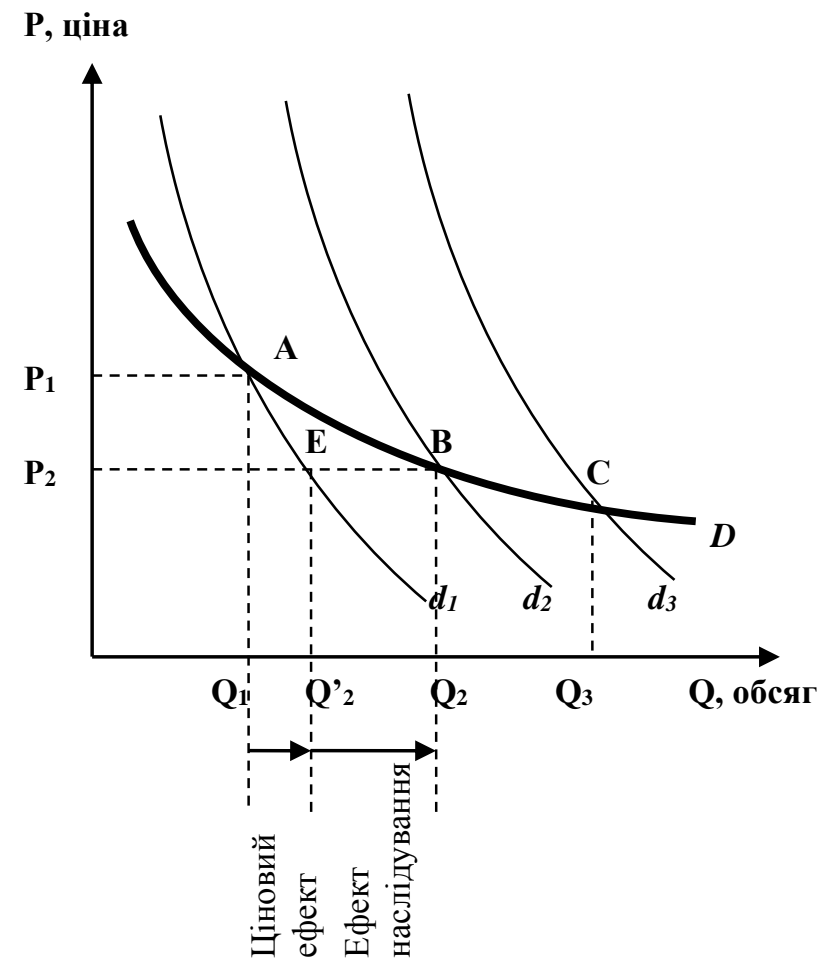

(2.a)
P, ціна

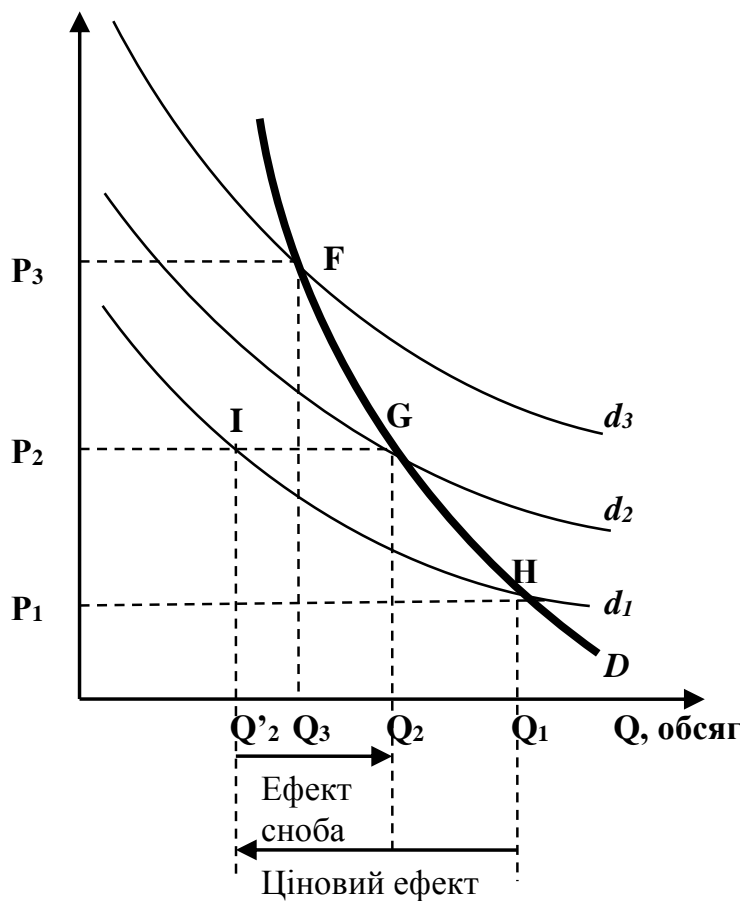

(2.6)

Рис. 2. Графічна інтерпретація зміни споживчого попиту внаслідок ефекту наслідування (2.a) та ефекту сноба (2.б)

Джерело: сформовано автором

Ефект сноба має протилежну дію до ефекту наслідування та відображає непереборне прагнення індивіда виокремитися із загальної маси, купуючи такі товари як колекційні автомобілі, витвори мистецтва, історичні цінності, ексклюзивний одяг, персонально розроблені туристичні подорожі тощо. Чим унікальніше благо, тим вища його корисність для сноба та більше прагнення володіти ним, незважаючи на вищу ціну. Дія ефекту сноба на вибір споживача проілюстровано на рис. 2.б. Чим ексклюзивніший товар та вища ціна, тим правіше та вище буде розташована крива індивідуального попиту. Це означає, що чим більше людей володіють аналогічним благом, тим меншим є попит сноба на нього. Крива ринкового попиту для товарів, що підпадають під дію ефекту сноба $\epsilon$ набагато менш еластичною, ніж для звичайних благ. За умови збільшення ціни із рівня $P_{1}$ до рівня $P_{2}$ згідно із законом попиту обсяг попиту мав би скоротитися від $Q_{1}$ до $Q_{2}$. Однак, оскільки ефект сноба протидіє ціновому ефекту, індивідуальний попит збільшується з $Q_{2}^{2}$ до $Q_{2}$, а споживач переміщується на крипу попиту $d_{2}$. Таким чином, ефект сноба зменшує реакцію у зміні обсягу попиту на зростання ціни.

Із становленням ринкових відносин та інтеграцією до світової спільноти споживання в українському суспільстві зазнало суттєвих змін. Нині його можна охарактеризувати як суперечливе сплетіння традиційних соціокультурних елементів, деформованих тоталітарним режимом, із яскраво вираженим орієнтиром на європейський зразок споживчої поведінки. Однак, підсилена 


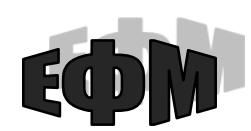

http://efm.vsau.org/

ефектом наслідування та ефектом сноба диспропорція бажань і платоспроможного попиту іноді спотворює раціональний вибір українського споживача невиправданим демонстраційним споживанням, обумовленим бажанням замаскувати своє незадовільне матеріальне становище.

Досліджуючи соціально-економічний розвиток України та поведінку вітчизняних споживачів, стає зрозуміло, що в сучасних умовах основним економічним чинником, що на неї впливає $-\epsilon$ рівень доходу [7]. Неконтрольоване зростання цін, невідповідна індексація доходів, низький рівень заробітних плат, недостатня соціальна підтримка малозабезпечених верств населення призвело до того, що в країні переважає аскетичний вид споживання (тобто орієнтований на задоволення базових потреб), причому вимушений, що обумовлено низьким рівнем реального доходу основної маси українців.

Здійснивши аналіз статистичних даних щодо диференціації життєвого рівня населення України (табл. 1), бачимо, що відсоток населення, яке має доход нижче законодавчо встановленого прожиткового мінімуму скоротився, але це й не дивно, адже за останні 5 років офіційний прожитковий мінімум збільшився лише на 568,8 грн, а сукупні номінальні доходи домогосподарств за цей період зросли майже в 2 рази (рис. 2).

Диференціація життєвого рівня населення України у 2014-2018 рр.

\begin{tabular}{|c|c|c|c|c|c|c|}
\hline Показники & 2014 & 2015 & 2016 & 2017 & 2018 & $\begin{array}{c}2018+/- \\
2014\end{array}$ \\
\hline $\begin{array}{l}\text { Середньорічний розмір законодавчо } \\
\text { встановленого прожиткового мінімуму (у } \\
\text { середньому на одну особу в місяць, грн) }\end{array}$ & 1176,0 & 1227,3 & 1388,1 & 1603,7 & 1744,8 & 568,8 \\
\hline \multicolumn{7}{|l|}{$\begin{array}{l}\text { Чисельність населення із середньодушовими } \\
\text { еквівалентними загальними доходами у } \\
\text { місяць, нижчими законодавчо встановленого } \\
\text { прожиткового мінімуму: }\end{array}$} \\
\hline млн осіб & 3,2 & 2,5 & 1,5 & 0,9 & 0,5 & $-2,7$ \\
\hline у \% до загальної чисельності населення & 8,6 & 6,4 & 3,8 & 2,4 & 1,3 & $-7,3$ \\
\hline $\begin{array}{l}\text { Середньорічний розмір фактичного } \\
\text { прожиткового мінімуму (у середньому на одну } \\
\text { особу в місяць, грн) }\end{array}$ & 1357,6 & 2257,0 & 2642,4 & 2941,5 & 3262,7 & 1905,1 \\
\hline \multicolumn{7}{|l|}{$\begin{array}{l}\text { Чисельність населення із середньодушовими } \\
\text { еквівалентними загальними доходами у } \\
\text { місяць, нижчими фактичного прожиткового } \\
\text { мінімуму: }\end{array}$} \\
\hline млн осіб & 6,3 & 20,2 & 19,8 & 13,5 & 10,6 & 4,3 \\
\hline у \% до загальної чисельності населення & 16,7 & 51,9 & 51,1 & 34,9 & 27,6 & 10,9 \\
\hline $\begin{array}{l}\text { Квінтильний коефіцієнт диференціації } \\
\text { загальних доходів населення, разів }\end{array}$ & 1,9 & 1,9 & 1,9 & 1,9 & 2,0 & 0,1 \\
\hline $\begin{array}{l}\text { Квінтильний коефіцієнт фондів (по загальних } \\
\text { доходах), разів }\end{array}$ & 3,1 & 3,2 & 3 & 3,3 & 3,3 & 0,2 \\
\hline
\end{tabular}

Джерело: Сформовано автором за даними Державної служби статистики України [5]

Зростання доходів обумовлене підвищенням мінімального та середнього рівня заробітних плат, трансфертних платежів (зокрема, субсидій та інших видів соціальної допомоги), доходів від підприємницької діяльності тощо. Однак, номінальне підвищення доходів не перекрило інфляційне зростання середнього рівня цін. Тому більш яскравим підтвердженням падіння купівельної спроможності вітчизняних споживачів є зростання на 4,3 млн осіб або на 10,9\% частки населення, яке має середньодушовий загальний доход нижчий фактичного прожиткового мінімуму $(3262,7$ грн). Причому останній зріс в 2,4 рази, тоді як законодавчо встановлений - лише в 1,48 рази. Невідповідне підвищення урядом прожиткового мінімуму штучно зменшує державні витрати на пенсійні та інші соціальні виплати, розрахунок яких на ньому базується. Така економія державного бюджету призводить до скорочення споживчих витрат, покупці поводяться більш економно, відмовляються від дорожчих та якісніших товарів, надають перевагу лише першочерговим товарам.

Сучасна криза споживання характеризується зміною загальної моделі поведінки вітчизняного споживача і призвела до здійснення покупок товарів переважно за акціями і на розпродажах та їхнього систематичного відстеження; скорочення обсягів покупок; повної відмови 


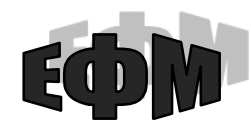

http://efm.vsau.org/

від покупки певних категорій товарів; переключення на більш дешеві бренди; пошуку місць, де можна купити товари за нижчою ціною; переходу на аналогічну продукцію вітчизняного/іноземного виробника; покупки товарів, які були у вжитку; переходу на товаризамінники; купівлі товарів у розстрочку тощо. [1]

Однією із проблем, що істотно скорочує споживчий попит на товари та послуги демонстраційного споживання є вимирання середнього класу. За даними економічних досліджень, частка середнього класу в Україні в загальній сукупності працездатного населення становить лише 0,83\% (297 тис. осіб), тоді як, наприклад, у США він складає 38\%, а в Японії 87\%. [4]. Зростає нерівність між багатшими та бідними прошарками суспільства, підтвердженням чого є певне підвищення квінтильного коефіцієнту диференціації загальних доходів населення (який розраховується як співвідношення мінімального рівня доходів серед найбільш забезпечених $20 \%$ населення до максимального рівня доходів серед найменш забезпечених $20 \%$ населення, ранжованого за показником середньодушових еквівалентних доходів) та квінтильного коефіцієнту фондів (який розраховується як співвідношення сумарних доходів найбільш та найменш забезпечених 20\% населення, ранжованого за показником середньодушових еквівалентних доходів) (табл. 1). В Україні спостерігається посилення ознак бідності та економічної депривації у сфері споживчих можливостей людей за наявних у суспільстві стандартів, поширення серед домогосподарств окремих проявів позбавлення в частині можливостей задоволення не тільки потреб, пов'язаних із розвитком особистості та забезпеченням належного рівня комфортності існування, а й мінімально необхідних фізіологічних потреб. У 2017 році в країні зафіксовано найбільший за період 2007-2017 років рівень бідності за ознакою вимушеного позбавлення особи можливості задовольняти свої базові потреби через відсутність доступу до основних матеріальних благ і соціальних ресурсів унаслідок нестачі коштів (за чотирма 318 ознак позбавлень) [9].

Основою формування бюджету споживача $є$ грошові надходження. У 2018 р. вони складали 89,9\% сукупних ресурсів домогосподарств, i їхня частка протягом останніх 9 років майже не змінилася. Вони включають оплату праці; доходи від підприємницької діяльності та самозайнятості, доходи від продажу сільськогосподарської продукції; пенсії, стипендії, соціальні допомоги, надані готівкою; грошову допомогу від родичів, інших осіб та інші грошові доходи. Домінантним джерелом грошових надходжень населення залишається заробітна плата, частка якої у 2018 році становила 54,5\% сукупних ресурсів домогосподарств (рис. 3), що на 6,9\% більше, ніж у 2010 році. Проте протягом зазначеного періоду спостерігається суттєве скорочення частки пенсій, стипендій, соціальної допомоги, наданої готівкою (на 5,9\%), адже пенсійний вік збільшився; багато пенсіонерів, які не в змозі прогодувати себе за рахунок державних виплат, змушені працювати; студенти не отримують стипендій, а щоб оплатити своє навчання підробляють в умовах неповного робочого дня; методика обрахунку соціальних виплат базується на заниженому відповідно реалій законодавчо встановленому прожитковому мінімумі; процедура отримання багатьох видів соціальної допомоги є доволі складною та ін. 3 іншого боку, збільшилися пільги та безготівкові субсидії на оплату житлово-комунальних послуг, електроенергії, палива. Найбільша їх частка становила 5,1\% у 2015 році , що на 4,5\% більше, ніж у 2010 році. У 2018 р. зазначений показник зменшився до 2,8\%, що на 2,5\% більше, ніж у 2010 році. Однією із причин такого зменшення $\epsilon$ ускладнення процедури та зміна умов отримання житлових субсидій, у зв'язку з чим багато сімей втратило право на їхнє одержання. Крім того, з 1 травня 2019 року зменшено соціальні нормативи на комунальні послуги: на постачання холодної води із 4 до 3,6 куб. метра на 1 особу в місяць (за відсутності централізованого постачання гарячої води) та із 2,4 до 2 куб. метра (за наявності централізованого постачання гарячої води); на водовідведення із 4 до 3,6 куб. метра на 1 особу в місяць; на використання природного газу із 4,5 до 4,0 куб. метра на 1 кв. метр опалюваної площі в місяць в опалювальний період; на використання теплової енергії із 0,0431 до 0,0383 Гкал на 1 кв. метр опалюваної площі в місяць в опалювальний період [11]. Як наслідок, це ще більше скоротить обсяг одержаних домогосподарствами субсидій, що в свою чергу збільшить частку їхніх витрат на оплату житлово-комунальних послуг та відповідно зменшить витрати на товари та послуги демонстраційного споживання.

Аналізуючи структуру споживчих сукупних витрат вітчизняних домогосподарств за останні 5 років, бачимо, що більше половини своїх доходів вони спрямовують на закупівлю продуктів харчування та безалкогольних напоїв. Це доволі високий показник, у порівнянні із розвинутими країнами світу. За даними Міністерства сільського господарства США Україна у 2018 році потрапила до топ-10 країн із найбільшими витратами на їжу.

Для порівняння, у США у 2017 році споживачі витратили на продукти харчування близько $7 \%$ доходів. У Європі найменше коштів на продукти харчування витрачають мешканці Люксембургу (8,7 \% свого доходу), у Великобританії та Нідерландах - близько $10 \%$, в Австрії, Швейцарії, Фінляндії - до $12 \%$. Зрозуміло, що чим вищий цей показник, тип менший рівень 


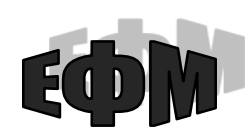

http://efm.vsau.org/

матеріального добробуту населення, оскільки споживачі не можуть собі дозволити демонстраційні товари для посилення свого статусу, особистісного розвитку, підвищення комфорту. В Україні менше 2\% витрат спрямовується на такі категорії як освіта та культура і відпочинок.

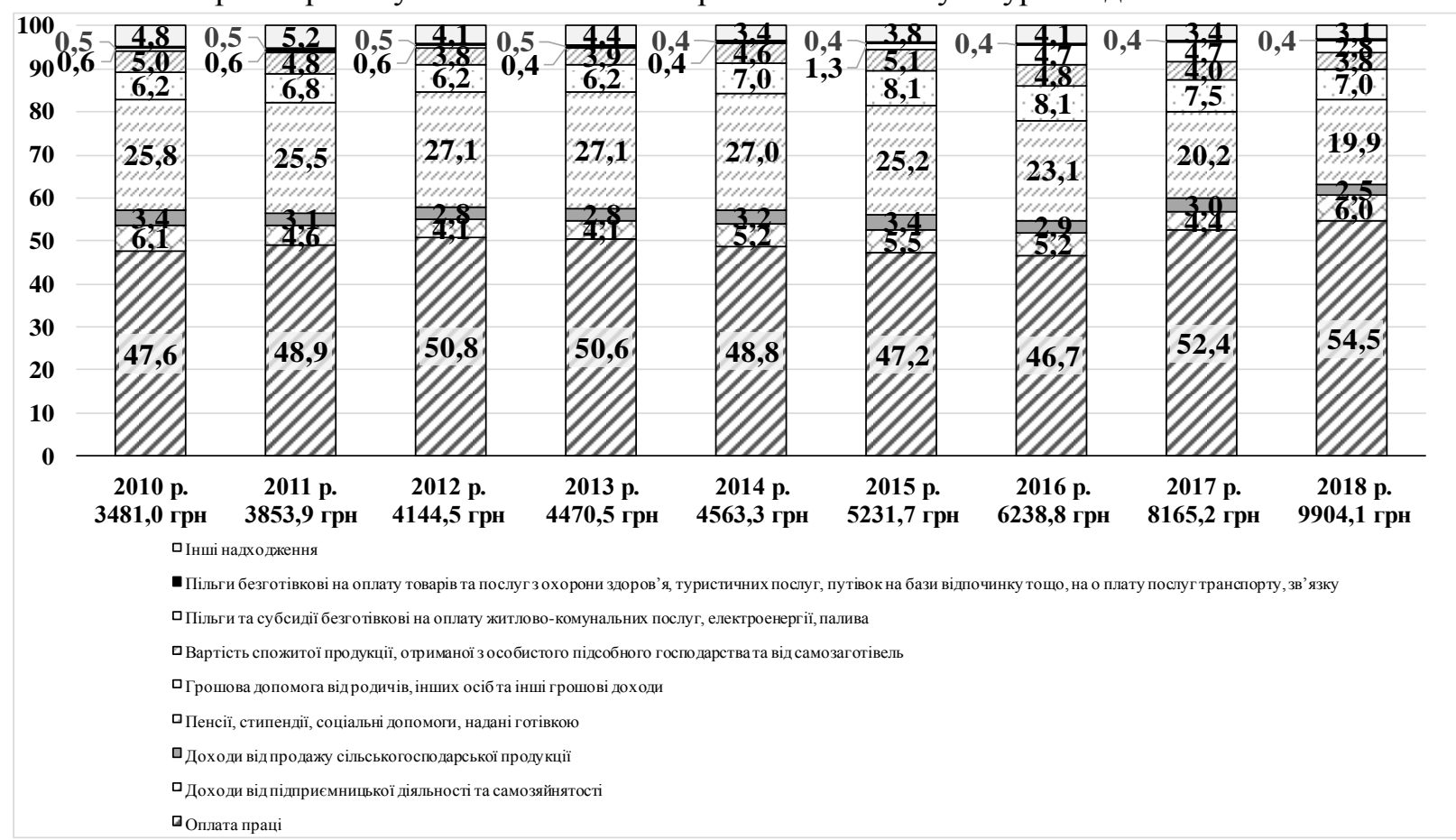

Рис. 3. Структура сукупних ресурсів в середньому за місяць у розрахунку на одне домогосподарство України у 2010-2018 роках, \% громадян не мають такої тенденції.

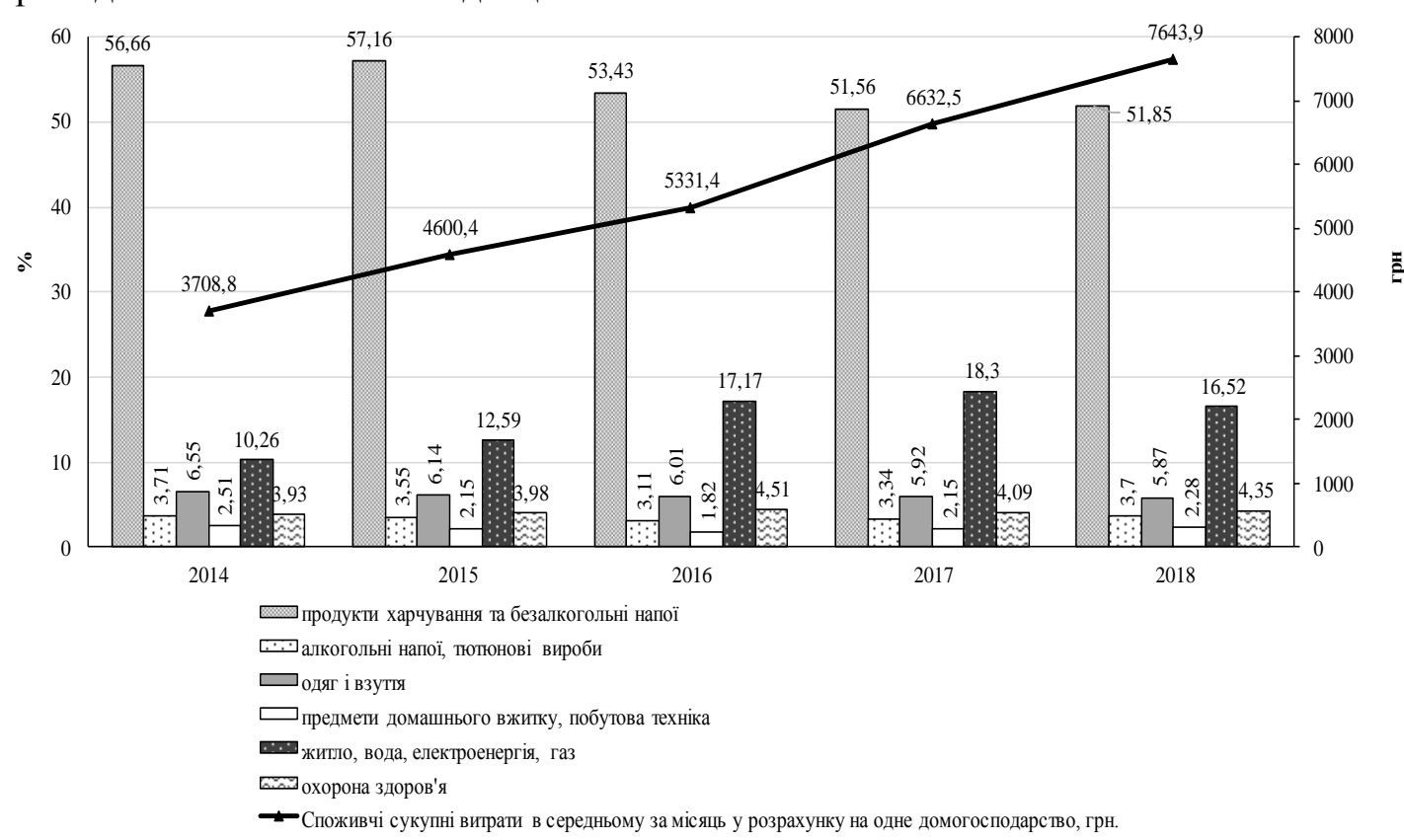

Pис. 4. Структура споживчих сукупних витрат домогосподарств України в середньому за місяць у 2014-2018 роках, \%

Джерело: Сформовано автором за даними Державної служби статистики України [5] 
Підтвердженням падіння купівельної спроможності та збільшення ознак депривації вітчизняних споживачів є зменшення обсягів споживання продуктів харчування протягом останніх п'яти років по всіх видах продукції (табл. 2). Більше того, фактичне споживання українцями продуктів харчування по половині категорій наближене до мінімальної норми або менше за неї та по всіх категоріях менше за раціональні норми, встановлені Міністерством охорони здоров'я України. Найбільший розрив спостерігається у категорії «молоко та молочні продукти»: пересічний українець не доїдає 9,3 кг та 12,6 кг відповідно до мінімальної та раціональної норм споживання даної продукції в середньому на місяць на одну особу.

Таблиия 2

Споживання продуктів харчування в домогосподарствах України у 2014-2018 роках (у перерахунку в первинний продукт) у середньому за місяць у розрахунку на одну особу

\begin{tabular}{|c|c|c|c|c|c|c|c|c|c|c|}
\hline \multirow[b]{2}{*}{ Види продуктів } & \multirow[b]{2}{*}{ 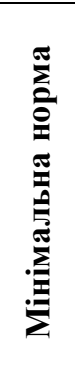 } & \multirow{2}{*}{ 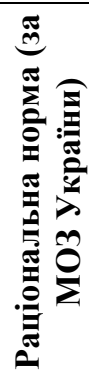 } & \multirow[b]{2}{*}{ 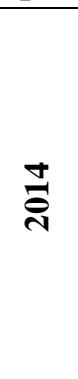 } & \multirow[b]{2}{*}{ 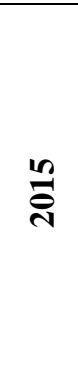 } & \multirow[b]{2}{*}{ ำ } & \multirow[b]{2}{*}{ 공 } & \multirow[b]{2}{*}{ 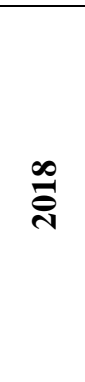 } & \multirow[b]{2}{*}{ 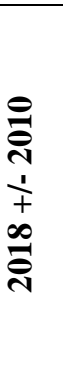 } & \multicolumn{2}{|c|}{$\begin{array}{c}\text { Споживання } \\
2018+/- \text { до }\end{array}$} \\
\hline & & & & & & & & & 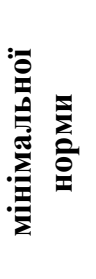 & 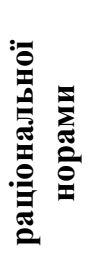 \\
\hline М'ясо і м'ясопродукти, кг & 4,3 & 6,7 & 4,9 & 4,6 & 4,7 & 4,7 & 4,9 & 0,0 & 0,6 & $-1,8$ \\
\hline Молоко і молочні продукти, кГ & 28,4 & 31,7 & 20,3 & 19,8 & 19,6 & 19,3 & 19,1 & $-1,2$ & $-9,3$ & $-12,6$ \\
\hline ЯйцЯ, шт. & 19,3 & 24,2 & 20,0 & 19,0 & 19,0 & 20,0 & 19,0 & -1 & $-0,3$ & $-5,2$ \\
\hline Риба і рибопродукти, кг & 1,0 & 1,7 & 1,6 & 1,2 & 1,2 & 1,3 & 1,4 & $-0,2$ & 0,4 & $-0,3$ \\
\hline Цукор, кг & 2,7 & 3,2 & 3,0 & 2,8 & 2,7 & 2,8 & 2,7 & $-0,3$ & 0,0 & $-0,5$ \\
\hline Олія та інші рослинні жири, кг & 0,7 & 1,1 & 1,7 & 1,6 & 1,5 & 1,5 & 1,5 & $-0,2$ & 0,8 & 0,4 \\
\hline Картопля, кг & 8,0 & 10,3 & 6,9 & 6,6 & 6,7 & 6,4 & 6,3 & $-0,6$ & $-1,7$ & $-4,0$ \\
\hline Овочі та баштанні, кг & 8,8 & 13,4 & 9,0 & 8,8 & 9,2 & 8,5 & 8,9 & $-0,1$ & 0,2 & $-4,5$ \\
\hline $\begin{array}{l}\text { Фрукти, ягоди, горіхи, } \\
\text { виноград, кг }\end{array}$ & 5,7 & 7,5 & 3,7 & 3,1 & 3,3 & 3,7 & 3,8 & 0,1 & $-1,9$ & $-3,7$ \\
\hline Хліб і хлібні продукти, кг & 7,8 & 8,4 & 9,0 & 8,5 & 8,3 & 8,4 & 8,3 & $-0,7$ & 0,5 & $-0,1$ \\
\hline
\end{tabular}

Джерело: Сформовано автором за даними Державної служби статистики Украӥни [5]

Проведений аналіз підтверджує висловлену на початку дослідження думку щодо переважання вимушеного аскетичного виду споживання серед українців. Адже, якщо населення не в змозі у повній мірі задовольнити свої базові фізіологічні потреби, зокрема в їжі, то це є свідченням доволі низької купівельної спроможності споживачів, що в свою чергу ускладнює перспективу збільшення ВВП та економічного зростання.

Щодо проявів інших видів споживання, слід зауважити, що в умовах військово-політичного конфлікту свідомі українці відмовляються від закупівлі продукції російського походження. Таку поведінку можна віднести до патріотичного споживання, спрямованого на захист національної економіки та підтримку вітчизняних виробників. Проте, багато пересічних громадян не усвідомлюють, що саме патріотичне споживання є запорукою збільшення національного доходу, ВВП, обсягів власного виробництва, і воно не повинно обмежуватися лише відмовою від закупівлі продукції країни-агресора, а передбачає надання переваги товарам та послугам вітчизняних підприємств. Тому одним із центральних завдань, націлених на забезпечення стійкого розвитку економіки України, є усвідомлення суспільством пріоритетності підтримки національних товаровиробників та заміщення споживання імпортної продукції вітчизняною, а також обмеження надмірного імпорту таких видів продукції, стосовно яких країна є достатньо самозабезпеченою власним виробництвом. Здійснення споживчого вибору на користь українських товарів та послуг посилить рівень національної, у тому числі продовольчої, безпеки.

Висновки. Споживання є одним із найважливіших процесів у суспільній системі, саме воно запускає механізми економічної активності як виробника, так і покупця. Проте, поведінка споживача $€$ мінливою, особливо коли йдеться про задоволення потреб вторинного характеру. У сучасних реаліях життя споживчий вибір не завжди є раціональним, а іноді навіть вимушеним, у зв'язку із негативним впливом певних соціально-економічних чинників. Зростання цін призводить до скорочення споживання в усіх сегментах товарної номенклатури, особливо у тих, що належать 


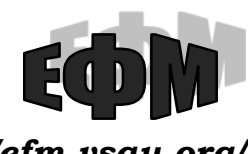

http://efm.vsau.org/

до демонстраційного споживання. Це вимагає невідкладного перегляду цінової політики підприємств та диверсифікації асортименту з урахуванням потреб та особливостей споживчої поведінки квінтильних груп населення за доходами.

Аналіз динаміки та структури споживчих витрат домогосподарств України свідчить про їхню високу чутливість до динаміки поточного реального доходу. Песимістичні очікування щодо власного економічного добробуту призводять до нівелювання споживчих потреб, скорочення незапланованих та спонтанних закупівель, економії або відмови від товарів та послуг не першої необхідності (у т.ч. подорожі, відпочинку), відкладання на пізніше дорогих покупок, зокрема інноваційних продуктів, товарів довготривалого користування. В Україні спостерігаються ознаки бідності споживача, причому серед працюючого населення, що значно обмежує споживчий попит. Для вирішення цієї проблеми необхідно здійснити низку заходів, спрямованих на удосконалення механізму державного регулювання цін та рівня доходів населення, системи соціального забезпечення, антиінфляційної політики.

Значна частка внутрішнього споживчого попиту задовольняється за рахунок імпортних товарів, що спричинене недостатньою конкурентоспроможністю українських товарів та низкою інших проблем політично-правого та економічного характеру, розв'язання яких вимагає з одного боку оптимізації національного виробництва та дотримання високих світових стандартів якості продукції, а з іншого - раціоналізації товарних потоків із застосуванням політики протекціонізму.

Проведене дослідження доводить, що споживання є багатогранною економічною категорією, що лежить у площині взаємодії виробника, споживача та держави й підпадає під впив особистісних, психологічних, економічних, соціокультурних, політичних чинників, а тому стимулювання споживчого попиту є комплексом організаційно-економічних, інституційних та правових заходів, спрямованих на покращення життєзабезпечення українського суспільства, розробка якого $є$ перспективою подальших досліджень у цій сфері.

\section{Список використаних джерел:}

1. Бажеріна К.В., Черненко О.В., Афанасьєва К.О. Зміна споживчої поведінки українців в умовах кризи. Ефективна економіка. 2018. № 4. [Електронний ресурс] Режим доступу: : $\mathrm{http}: / / \mathrm{www} \cdot \mathrm{economy} \cdot n a y k a \cdot c o m \cdot u a / ? \mathrm{op}=1 \& \mathrm{z}=6281$

2. Бондарчук Т.В. Модель поведінки споживача: теоретико-методологічні аспекти. Глобальні та національні проблеми економіки. Вип. 11. 2016. С. 3 - 7.

3. Брояка А.А. Поведінка споживача в сучасній ринковій економіці. Економіка, фінанси, менеджмент: актуальні питання науки та практики. 2019. № 4. С. 32-40.

4. Гуржий Т.О. Нерівність як фактор росту бідності та вимирання середнього класу. Причорноморські економічні студії. Вип. 30-2, 2018. С. 52-56.

5. Державна служба статистики України. [Електронний ресурс] Режим доступу: http://www.ukrstat.gov.ua/

6. Євтушевська О.В. Основні види споживання та його вплив на природно-ресурсний потенціал. Ефективна економіка. 2014. №11. [Електронний ресурс] Режим доступу: http://www.economy.nayka.com.ua/?op=1\&z=3496

7. Євтушевська О.В. Особливості поведінки споживачів на ринку в сучасних умовах. Інвестиції: практика та досвід. 2016. №20. С. $22-24$.

8. Жовковська Т. Формування моделі поведінки споживача. Економічний дискурс. 2017. Вип. 2. С. $9-18$.

9. Звіт про результати аналізу виконання заходів з реалізації стратегії подолання бідності. К: Розрахункова палата, 2018. 94 с. Електронний ресурс] Режим доступу: http://www.acrada.gov.ua/doccatalog/document/16757712/Zvit_23-3_2018.pdf

10.Каправий В.В., Бондарчук А.Б. Використання ефекту Торстейна Веблена 3 метою збільшення обсягів реалізації товарів демонстраційного споживання в умовах споживчої кризи. Формування ринкових відносин в Україні. №4 (167), 2015. С. 123-127.

11.Постанова Кабінету Міністрів України від 27 грудня 2018 року № 1176 про зміни до Постанови Кабінету Міністрів України від 6 серпня 2014 року № 409 «Про встановлення державних соціальних стандартів у сфері житлово-комунального обслуговування» [Електронний ресурс] Режим доступу: https://zakon.rada.gov.ua/laws/show/409-2014-\%D0\%BF.

12.Про затвердження Методики комплексної оцінки бідності. Наказ Міністерства соціальної політики України, Міністерства економічного розвитку і торгівлі України, Міністерства фінансів України, Державної служби статистики України, Національної академії наук України від 18.05.2017 № 827/403/507/113/232 [Електронний ресурс] Режим доступу: https://zakon.rada.gov.ua/laws/show/z0728-17?lang=uk 


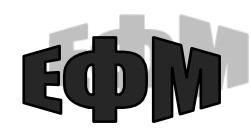

http://efm.vsau.org/

13.Решетнікова І.Л., Сагайдак М.П. Вплив економічної кризи на поведінку вітчизняних споживачів і сприйняття інновацій. Маркетинг і менеджмент інновацій, 2016, № 4. С. 191-205.

14.Сюсель Ю. Соціофілософський аспект споживацької поведінки як комунікативної дії : монографія. К. : ТОВ «НВП «Інтерсервіс», 2017. 182 с.

\section{Reference}

1. Bazherina K.V., Chernenko O.V., Afanasyeva K.O. (2018) Zmina spozhyvchoi povedinky ukraintsiv $\mathrm{v}$ umovakh kryzy [Changes in consumer behavior in times of crisis]. Efektyvna ekonomika - Effective economy. vol. 4. Retrieved from http://www.economy.nayka.com.ua/?op=1\&z=6281 [in Ukrainian].

2. Bondarchuk T.V. (2016). Model povedinky spozhyvacha: teoretyko-metodolohichni aspekty [Consumer behavior model: theoretical and methodological aspects]. Hlobalni ta natsionalni problemy ekonomiky - Global and national problems of the economics, Vol. 11, pp. 3 - 7 [in Ukrainian].

3. Broyaka A.A. (2019). Povedinka spozhyvacha v suchasnii rynkovii ekonomitsi [Consumer behavior in the modern market economy]. Ekonomika, finansy, menedzhment: aktualni pytannia nauky ta praktyky Economics, finance, management: topical issues of science and practical activity. № 4, p 32-40 [in Ukrainian].

4. Hurzhyi T.O. (2018). Nerivnist yak faktor rostu bidnosti ta vymyrannia serednoho klasu. [Inequality as a factor in the growth of poverty and the extinction of the middle class]. Prychornomorski ekonomichni studii - Black Sea Economic Studies. Vol. 30-2, pp. 52-56. [in Ukrainian].

5. Derzhavna sluzhba statystyky Ukrayiny [Official site of the State Statistics Service of Ukraine]. Retrieved from http://www.ukrstat.gov.ua/ [in Ukrainian].

6. Yevtushevska O.V. (2014). Osnovni vydy spozhyvannia ta yoho vplyv na pryrodno-resursnyi potentsial [Main types of consumption and its impact on an ecological potential]. Efektyvna ekonomika Effective economy. vol. 11. Retrieved from http://www.economy.nayka.com.ua/?op=1\&z=3496 [in Ukrainian].

7. Yevtushevska O.V. (2016). Osoblyvosti povedinky spozhyvachiv na rynku v suchasnykh umovakh [Peculiarities of consumers' behavior on market under modern conditions]. Investytsii: praktyka ta dosvid - Investments: practice and experience, \# 20, pp. 22 - 24 [in Ukrainian].

8. Zhovkovska T. (2017). Formuvannia modeli povedinky spozhyvacha [Forming the model of consumer behavior]. Ekonomichnyi dyskurs - The Economic Discourse, Issue 2, pp. 9 - 18 [in Ukrainian].

9. Zvit pro rezultaty analizu vykonannia zakhodiv z realizatsii stratehii podolannia bidnosti [Report on the results of the analysis of the implementation of measures to implement the poverty reduction strategy] (2018). Kyiv: Rozrakhunkova palata - Court of Accounts, 94 p. Retrieved from http://www.acrada.gov.ua/doccatalog/document/16757712/Zvit_23-3_2018.pdf [in Ukrainian].

10. Kapravyi V.V., Bondarchuk A.B. (2015). Vykorystannia efektu Torsteina Veblena z metoiu zbilshennia obsiahiv realizatsii tovariv demonstratsiinoho spozhyvannia $\mathrm{v}$ umovakh spozhyvchoi kryzy [Using the Thorstein Veblen Effect to Increase Sales of Demonstration Consumption Products in a Consumer Crisis]. Formuvannia rynkovykh vidnosyn v Ukraini - Market Relations Development in Ukraine. №4 (167), pp. 123-127. [in Ukrainian].

11. Postanova Kabinetu Ministriv Ukrainy vid 27 hrudnia 2018 roku № 1176 pro zminy do Postanovy Kabinetu Ministriv Ukrainy vid 6 serpnia 2014 roku № 409 «Pro vstanovlennia derzhavnykh sotsialnykh standartiv u sferi zhytlovo-komunalnoho obsluhovuvannia» [Resolution of the Cabinet of Ministers of Ukraine of December 27, 2018 No. 1176 amending the Cabinet of Ministers of Ukraine Decree of August 6, 2014 \# 409 "On Establishing State Social Standards in the Housing and Communal Services"] (2018). Legislation of Ukraine. Retrieved from: https://zakon.rada.gov.ua/laws/show/4092014-\%D0\%BF [in Ukrainian].

12. Pro zatverdzhennia Metodyky kompleksnoi otsinky bidnosti. Nakaz Ministerstva sotsialnoi polityky Ukrainy, Ministerstva ekonomichnoho rozvytku i torhivli Ukrainy, Ministerstva finansiv Ukrainy, Derzhavnoi sluzhby statystyky Ukrainy, Natsionalnoi akademii nauk Ukrainy vid 18.05.2017 № 827/403/507/113/232 [On approval of the Comprehensive Poverty Assessment Methodology. Order of the Ministry of Social Policy of Ukraine, Ministry of Economic Development and Trade of Ukraine, Ministry of Finance of Ukraine, State Statistics Service of Ukraine, National Academy of Sciences of Ukraine of 18.05.2017 \# 827/403/507/113/232]. (2017). Legislation of Ukraine. Retrieved from: https://zakon.rada.gov.ua/laws/show/z0728-17?lang=uk [in Ukrainian].

13. Reshetnikova I.L., Sahaidak M.P. (2016). Vplyv ekonomichnoi kryzy na povedinku vitchyznianykh spozhyvachiv i spryiniattia innovatsii [The impact of the economic crisis on domestic consumers behavior and perception of innovation]. Marketynh i menedzhment innovatsii - Marketing and Management of Innovations, № 4. pp. 191-205 [in Ukrainian]. 


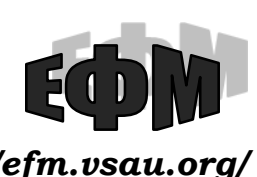

14. Siusel Yu. (2017). Sotsiofilosofskyi aspekt spozhyvatskoi povedinky yak komunikatyvnoi dii : monohrafiia [Sociophilosophical aspect of consumer behavior as a communicative action: a monograph]. Kyiv : TOV «NVP «Interservis», 182 p. [in Ukrainian].

\section{Інформація про автора}

БРОЯКА Антоніна Анатоліївна - кандидат економічних наук, доцент кафедри економіки, Вінницький національний аграрний університет (21008, м. Вінниця, вул. Сонячна, 3, e-mail: broyaka@vsau.vin.ua).

BROYAKA Antonina - Candidate of Economic Sciences, Associate Professor of the Department of Economics, Vinnytsia National Agrarian University (3, Soniachna Str., Vinnytsia, 21008; e-mail: broyaka@vsau.vin.ua).

БРОЯКА Антонина Анатольевна - кандидат экономических наук, доцент кафедры экономики, Винницкий национальный аграрный университет $(21008$, г. Винница, ул. Солнечная, 3 , e-mail: broyaka@vsau.vin.ua).

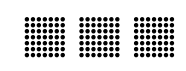

УАК: 631.439.147

DOI: $10.37128 / 2411-4413-2019-6-4$

\author{
ХАЕЦЬКА О.П., \\ кандидат економічних наук, \\ доцент кафедри економіки, \\ Вінницький національний аграрний \\ університет \\ (м. Вінниця)
}

\section{ПЕРСПЕКТИВИ РОЗВИТКУ РИНКУ ОРГАНІЧНОӦ ПРОДУКЦІї В УКРАÏHI TA CBITI ${ }^{\circ}$}

У статті висвітлено сучасний стан розвитку світового та вітчизняного ринку органічної продукиї̈, зазначено краӥни, де спостерігаються найвищі темпи розвитку сертифікованого виробництва, країни з найбільшим споживанням органічної продукиї на душу населення та країни з найбільшими площами органічних сільськогосподарських земель. Проаналізовано ринок органічної продукиї в Україні від зародження до сучасного стану із зазначенням усіх стадій розвитку та проблем, що виникали, також наведено основні Закони щзодо органічного виробництва, визначено сертифіковані органічні продукти, країни та компанії щуо функціонують на вітчизняному ринку.

Зазначено площі земель із органічним статусом, загальну кількість органів сертифікації, кількість операторів на даному ринку у розрізі областей України. У статті проводиться порівняльний аналіз українського органічного виробництва зі світовим виробництвом, зазначено країн-лідерів за площами зайнятими під органічним виробництвом. Визначено перелік сертифікованих в Украйні видів органічних продуктів, які споживаються як на внутрішньому ринку так і експортуються в різні країни світу. У статті розглянуто динаміку внутрішнього ринку органічної продукиї за 2002-2017 роки.

Наведено основні принципи органічного сільського господарства, які направленні на збереження довкілля, природних ресурсів а також запропонований механізм стимулювання органічного виробниитва аграрними підприємствами. Також описано переваги даного виробництва, серед яких: переваги для здоров'я, екологічні, сочіальні та економічні переваги.

Визначено нагальні проблеми ринку органічної продукиії, запропоновано напрями державної політики у сфері органічного виробництва, щя сприятимуть розвитку органічного виробництва в Україні та просування вітчизняної органічної продукції в інші країни світу.

Ключові слова: ринок органічної продукції, органічне виробництво, органічна продукція, сертифіковане виробництво, виробництво сільськогосподарської продукції, екологічно чисті продукти харчування.

Рис. 7. Табл. 1. Літ 19. 